\title{
RESULTS OF PILOT INVESTIGATION OF STRATEGIC MARKETING MANAGEMENT AT HIGH SCHOOLS
}

\author{
[Výsledky pilotního šetření strategického marketingového řízení na úrovni \\ středních škol]
}

\author{
Martina Colledani ${ }^{1}$ \\ ${ }^{1}$ Slezská univerzita, Obchodně podnikatelská fakulta, Univerzitní nám. 1934/3,733 40 Karviná \\ Email:mcolledani@seznam.cz
}

\begin{abstract}
The article focuses on strategic marketing management in high schools and generalizes the results of previous investigations. Strategic management focuses primarily on long-term planning organization, which is a long-planned process that leads to the goal defined by the organization. The competitive environment is considered the main factor formulating the vision, mission and strategic goals of the organization. This deliberate and purposeful activity, led by the organization's competitive environment, possesses a much greater chance of survival, but also for success. Unfortunately, in the Czech Republic high school system is not a competitive environment and it is not ready to face competition at all. The situation is different at colleges that already understand that a student must "fight" as well as the company's customers and clients. Sophisticated school concept should be fundamentally similar to one of each company. The aim of the article is to present the results of a pilot research focused on strategic marketing management in high schools and to generalize the results of previous investigations. The theoretical part deals with strategic marketing management at the high school level. Respondent sample includes 34 secondary schools in the region Novy Jicin and Frydek-Mistek. Primary research was conducted via questionnaire and interview with the record. Research shows that schools have a clue about what the strategic management, marketing mix or plan are, but in most cases they do not know how to do it. Their reactions are mostly intuitive. When creating the end, the school decisions are not even based on the simplest SWOT analysis. When creating a strategy for the development of school in most cases they focused mainly on the internal environment of the school, not on the target markets and marketing mix.
\end{abstract}

Keywords: advertising, communication mix, direct marketing, modern forms of marketing communication, nonprofit organization, sales promotion.

JEL classification: M390

Doručeno redakci: 6.3.2017; Recenzováno: 20.3.2017; 8.4.2017; Schváleno k publikování: 31.5.2017

\section{Úvod}

Cílem článku je pojednání o strategickém marketingovém ř́zení v oblasti středních škol a zobecnění výsledků dosavadního šetření. Strategické řízení se zaměřuje především na dlouhodobé plánování organizace, tedy na dlouhodobě plánované procesy, které organizaci vedou k vytýčenému cíli. V konkurenčním prostředí se za hlavní považuje formulování vize, poslání a strategických cílů organizace. Tato promyšlená a cílevědomě vedená činnost organizace má v konkurenčním prostředí mnohem větší šanci na přežití, ale také na úspěch. V České republice bohužel střední školy zatím na konkurenční prostředí nereagují a nejsou připravené konkurenci vůbec čelit. Jiná je situace u vysokých škol, které již pochopily, že o studenty musí „bojovat“" stejně jako firmy o zákazníky a klienty. Promyšlená koncepce školy by měla být naprostou samozrrejmostí, tak jako koncepce každé firmy. Bohužel v minulých letech se jen velmi málo škol zamýšlelo nad podstatou svého bytí. Byly někým zřízeny, žáci měli zájem o studium, tudíž nebylo potřeba tuto situaci řešit. S úbytkem žáků se však spousta škol dostala do problémů. Neměly tradici, kulturu, dobrou image, a začalo docházet k zánikům škol nebo jejich slučování. Podle Českého statistického úřadu (dále jen „ČSÚ“) se počet středních škol od roku 2006 snižuje a kapacita současných škol není naplněná. ČSÚ uvádí naplněnost střední škol jen na $60 \%$ a méně. Další faktor, který hraje významnou roli, je 
nezaměstnanost především absolventi̊ středních škol, která se pohybuje vysoko nad republikovým průměrem. Školy by se měly naučit reagovat na současné i budoucí potřeby trhu práce a přizpůsobit jim své vzdělávací programy a celkovou strategii řízení školy. Strategické plánování ve školství je tedy nutností, a pokud chce být škola životaschopná, musí mít cíle, vize, strategii a uplatňovat svůj marketingový plán.

$\mathrm{Z}$ praxe je vidět potřeba měnit v řízení školy zaběhlé stereotypy a chovat se tržně. Škola přece nemusí realizovat pouze projekty související přímo se vzdělávacím programem, ale měla by se celkově zapojovat do života společnosti. Hlavním cílem je efektivně fungující škola, o kterou je dlouhodobě zájem. Potřebu marketingové komunikace si školy uvědomují poměrně více. Marketingové prostředí školy je dynamické a škola bez plánované marketingové strategie bude mít malou šanci se na trhu udržet. Úkolem marketingové strategie není jen vytvořit produkt, ale především ho zákazníkům prezentovat a ukázat, že splňuje všechny požadavky k uspokojení potřeb. Ve školství tento hlavní aspekt představují lidé - ředitel, pedagogové, absolventi, sociální partneři, potencionální zaměstnavatelé, kteří ukazují, jak kvalitní škola je. A škola, která nebude mít představu o tom, jak bude vypadat za pět let, nebude se zabývat svým posláním, vizí, strategií, taková škola bude mít velmi malou šanci se na trhu udržet.

\section{Marketingové strategické řízení školy}

Ředitel školy jako lídr celé organizace by měl vědět, kam chce svou školu směřovat a jakou vizi bude sdílet nejen se svými zaměstnanci, ale i se zřizovatelem. V dnešní době jsou na ředitele škol kladeny v oblasti řízení celkového managementu školy vyšší a vyšší nároky.

V odborné literatuře můžeme najít různé definice strategického managementu. Michalko uvádí „,...je to proces systematického provádění všech manažerských funkci a efektivního využivání všech zdrojü podniku $k$ dosažení stanovených podnikových cílì... ".(Michalko 2007, str. 8) Základní proces strategického plánování tvoří strategická analýza, formulace strategie, implementace strategie a strategický audit. Mintzberg vymezil strategii jako 5P - plan, ploy, pathern, position, perspektive. (Jünger 2007) Horáková v obecné rovině popisuje strategii jako „,... určité schéma postupu, které naznačuje, jak za daných podmínek dosáhnout vytyčených cílů... " (Horáková 2003, s. 11.) Marketingové strategické řízení by mělo určovat cestu firmy ke splnění dlouhodobých cílů a poslání firmy, tzn. odpovídat na otázku, jak dojdeme ke stanoveným cílům. Mezi základní pojmy tedy patří poslání, vize, cíle a strategie. Výběr a formulace strategie patří $\mathrm{k}$ nejzávažnějším krokům v řízení firmy. Firma musí znát, kdo jsou její cíloví zákazníci a jak bude uspokojovat jejich potřeby. Produkt, který škola na trhu nabízí, je tedy oproti firmě vázán legislativou a její plnění je pravidelně kontrolováno. Aby však mohla fungovat, musí pro tento svůj produkt najít dostatek zákazníků - studentů, nebot' podle počtu studentů se odvíjí finanční stránka školy. Tedy princip stejný jako u firmy - prodaný produkt přináší zisk. Zisk není hlavním cílem školy, přesto se velikost financí podílí na konkurenceschopnosti (Fotr 2012).

Na tomto základě se sestavuje marketingový mix a strategie marketingového mixu - výrobková strategie, cenová strategie, distribuční strategie a komunikační strategie. Výrobková strategie rozlišuje strategie pro individuální výrobky (většinou se strategie tvoří podle životního cyklu výrobku), pro výrobkovou řadu a výrobkový mix (Jakubíková 2009). Základním produktem školy je samotný vzdělávací program. Atraktivitu produktu dodávají právě aktivity jako exkurze, zahraniční stáže a praxe studentů, možnosti dalšího vzdělávání (např. jazykové certifikáty, odborné kurzy apod.). Velmi důležitým faktorem je samotná image školy a také kultura. Image je výsledkem prezentace, respektive vnímání prezentace firmy či školy veřejností. Př̀edstavuje určitou zkratku zhodnocení firmy či školy a skládá se z objektivních 
i subjektivních, správných ale i nesprávných představ, postojů a zkušeností jednotlivce a skupiny lidí o určité firmě či škole nebo vzdělávacím programu (Eger 2000). Cenu bychom ve školství mohli považovat za nedůležitou, protože kromě soukromého školství se školné neplatí. Výši nákladů však představují především učební pomůcky, doprava, ubytování, stravné, mimoškolní aktivity jako exkurze, sportovní pobyty, výlety apod. (Světlík 2009). Umístění školy je poměrně silným faktorem v rozhodovacím procese. U škol se předpokládá, že budou sloužit pro určitou spádovou oblast. Propagaci školy by neměly tvořit jen letáky oborů, ale komunikační mix by měl být celkově promýšlený proces. Mezi nejčastěji používané nástroje patří klasické prvky marketingové komunikace - letáčky, propagační tiskoviny, web školy, Facebook a vlastní prezentace školy. Firma nebo škola by měla svou činnost zakládat na bohatství, které jí přináší lidský faktor. Osobnost pedagogického pracovníka však v dnešní době ztratila na důležitosti. Škola je posuzovaná jako úspěšná podle toho, jak kvalitní učitelé v ní pracují. Prostředí a procesy ve škole navazují na celkovou organizační strukturu školy. $\mathrm{Na}$ těchto indikátorech by měla škola stavět svou vizi a dlouhodobé cíle.

\section{Charakteristika odvětví s ohledem na předmět zkoumání}

Oblast školství se řadí do neziskových oblastí. Neziskové organizace jsou společnosti, které netvoří zisk a Občanský zákoník je charakterizuje jako veřejně prospěšnou společnost. V § 146 - 150 Občanského zákoníku 89/2012 Sb. se uvádí: „, ...Veřejně prospěšná je právnická osoba, jejímž posláním je přispivat v souladu se zakladatelským právním jednáním vlastní činností k dosahování obecného blaha, pokud na rozhodování právnické osoby mají podstatný vliv jen bezúhonné osoby, pokud nabyla majetek z poctivých zdrojů a pokud hospodárně využivá své jměni k veřejně prospěšnému účelu.... " Pokud budeme školu chápat jako firmu poskytující vzdělávání, pak studenti jsou uživatelé těchto služeb, kteří mají své potřeby, požadavky a přání. Jedná se tedy o instituci, která nemá hlavní cíl tvorbu zisku, poskytuje služby a je dílčí části neziskového sektoru. Světlík ř́zení školy definuje jako ,... proces ř́zení, jehož výsledkem je poznání, ovlivňování a v konečné fázi uspokojení potřeb a přaní zákazníkủ a klientù školy efektivním způsobem zajištujícím současně splnění cílů školy. " (Světlík 2009, str. 19). To znamená, že hlavním cílem strategického řízení je v podstatě efektivním způsobem fungující škola. Komunikační mix v neziskových organizacích se musí zaměřit především na cílovou skupinu a efektivnost sdělení. Vzhledem k omezeným finančním zdrojům by měly neziskové organizace dále volit i vhodné médium (Hannagan 1996).

V posledních letech s rychle se vyvíjejícím prostředím, globalizací, novými požadavky na úroveň vzdělávání a především s ubývajícím počtem studentů se mění řízení všech škol, jak je vidět na obrázku 1.

\footnotetext{
${ }^{1}$ Zdroj: Webový portál Zákony pro lidi.cz [online][vid. 15. záři 2015]. Dostupné z <http://www.zakonyprolidi.cz/cs/201289\#cast1-hlava3-dil1>
} 
Obrázek 1: Vývoj počtu 15letých osob v ČR v letech 1980-2025

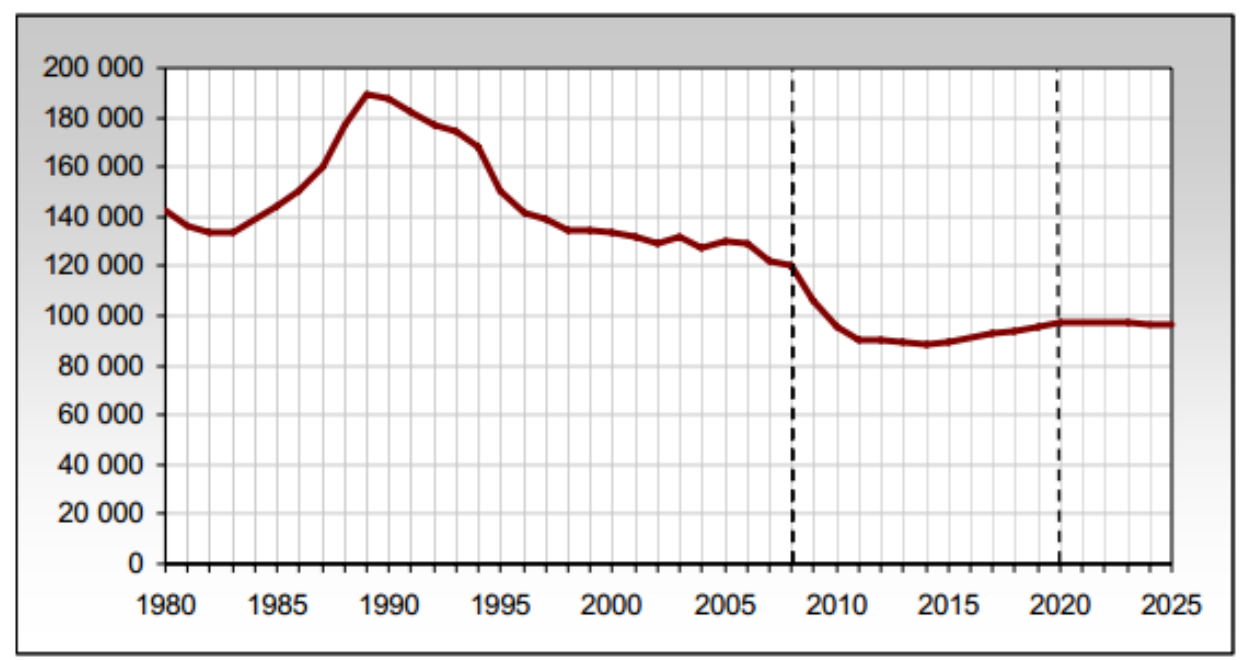

Zdroj: NUV [online][vid 1.12.2014] Dostupné z

http://www.nuv.cz/uploads/Vzdelavani_a_TP/VYVOJ08_pro_www.pdf

V České republice je škola právnická osoba a podle zákona 561/2004 Sb. jí zřizuje ministerstvo, kraj, obec, svazek obcí nebo jiná právnická nebo fyzická osoba. V tabulce 1 a 2 jsou výčty středních škol a počty žáků v rámci celé České republiky.

Tabulka 1: Počet středních škol v ČR

\begin{tabular}{|c|c|c|c|}
\hline Sledovaný parametr ČR (statistika MŠMT) & $2013 / 2014$ & $2014 / 2015$ & $2015 / 2016$ \\
\hline Počet SŠ celkem & 1331 & 1310 & 1304 \\
\hline Podíl veřejných škol (v \%) & 74,2 & 74,2 & 74,5 \\
\hline Podíl soukromých škol (v \%) & 23 & 22,8 & 22,5 \\
\hline Podíl církevních škol (v \%) & 2,8 & 3,0 & 3,0 \\
\hline Počet tř́íd v SŠ & 18823 & 18455 & 18269 \\
\hline Podíl tříd v oborech středního vzdělávání (v \%) & 1,4 & 1,5 & 1,7 \\
\hline Podíl tříd v oborech středního vzdělávání s výučním listem(v \%) & 25,8 & 26,0 & 25,9 \\
\hline Podíl tříd v oborech středního vzdělávání s maturitní zkouškou (v \%) & 72,8 & 72,5 & 72,4 \\
\hline
\end{tabular}

Zdroj: Výroční zpráva České školní inspekce

Tabulka 2: Počet žáků ve středních školách v ČR

\begin{tabular}{|l|c|c|c|}
\hline Sledovaný parametr ČR (statistika MŠMT) & $\mathbf{2 0 1 3 / 2 0 1 4}$ & $\mathbf{2 0 1 4 / 2 0 1 5}$ & $\mathbf{2 0 1 5 / 2 0 1 6}$ \\
\hline Počet žáků v SŠ & 448792 & 435542 & 427107 \\
\hline Podíl žáků v oborech gymnáziích (v \%) & 28,6 & 29,3 & 30 \\
\hline $\begin{array}{l}\text { Podíl žáků v oborech s maturitní zkouškou (v \%) bez nástavbového } \\
\text { studia }\end{array}$ & 71,9 & 72,5 & 73,2 \\
\hline Podíl žáků se zdravotním postižením (v \%) & 4,4 & 4,6 & 4,7 \\
\hline Počet nově p̌rijatých žáků do 1. ročníků - bez nástavbového studia & 120053 & 117725 & 116077 \\
\hline Počet nově přijatých žáků do 1. ročníků oborů s maturitní zkouškou & 60,7 & 61,7 & 62,8 \\
\hline Počet cizinců v SŠ & 9147 & 8837 & 8763 \\
\hline
\end{tabular}

Zdroj: Výroční zpráva České školní inspekce

V Moravskoslezském kraji jsou zřizovateli škol kraj, obec, církev, ministerstvo a fyzické nebo právnické osoby (dále soukromník). Celkový počet středních škol je 131. V tabulce 3 je vidět, že naplněnost je průměrně kolem $60 \%$. 
Tabulka 3: Počty žáků a středních škol v Moravskoslezském kraji a ČR a jejich naplněnost

\begin{tabular}{|l|l|c|c|c|c|}
\hline & & $\mathbf{2 0 1 3 - 1 4}$ & $\mathbf{2 0 1 4 - 1 5}$ & $\mathbf{2 0 1 5 - 1 6}$ & $\mathbf{2 0 1 6 - 1 7}$ \\
\hline Moravskoslezský kraj & počet škol & 130 & 128 & 134 & 131 \\
\hline & počet žáků & 53697 & 51101 & 50978 & 50452 \\
\hline & průměr počtu žáků na školu & 413,1 & 399,2 & 380 & 385 \\
\hline & průměrné naplnění kapacity $(v \%)$ & 62,3 & 60,4 & 60,1 & 59,8 \\
\hline & počet škol & 1331 & 1310 & 1304 & 1302 \\
\hline & počet žáků & 448792 & 435542 & 427107 & 421674 \\
\hline & průměr počtu žáků na školu & 372,4 & 367,7 & 328 & 324 \\
\hline & průměrné naplnění kapacity $(v \%)$ & 62,4 & 61,6 & 60,8 & 60,2 \\
\hline
\end{tabular}

Zdroj: Údaje z Výroční zprávy České školní inspekce a vlastní zpracování

Nejčastějším zřizovatelem střední školy v rámci Moravskoslezského kraje je kraj a soukromník, tedy fyzická nebo právnická osoba. (viz tabulka 4).

Tabulka 4: Počty stř̌edních škol v Moravskoslezském kraji

\begin{tabular}{|l|c|}
\hline Zřizovatel & Počet škol \\
\hline Kraj/Obec/MŠMT & 90 \\
\hline Církev & 3 \\
\hline Soukromník & 38 \\
\hline Celkem & 131 \\
\hline
\end{tabular}

Zdroj: Výroční zpráva České školní inspekce

Každý kraj zpracovává dokument zaměřující se na dlouhodobé záměry vzdělávání a jeho rozvoje v daném kraji. Moravskoslezský kraj svi̊j dokument „Dlouhodobé záměry vzdělávání a rozvoje vzdělávací soustavy Moravskoslezského kraje“2 (dále jen „DZVRVS MSK“) zpracoval od roku 2015 do roku 2020. Navazuje na Dlouhodobý záměr vzdělávání a rozvoje vzdělávací soustavy ČR na období 2015-2020, Regionální inovační strategii Moravskoslezského kraje a Strategii rozvoje Moravskoslezského kraje na léta 2009-2020. Všechny školy by pro své strategické plánování měly z dokumentu DZVRVS MSK vycházet.

\section{Pilotní výzkum}

Pilotní šetření proběhlo na vybraných školách a jeho hlavním cílem bylo ověření proveditelnosti dotazníkového šetření a správnost stanovení hypotéz. Jednalo se o kvantitativní výzkum, na základě kterého byly pomocí škálových otázek získány nominální i ordinální proměnné. Bylo vybráno 34 středních odborných škol z regionu Nový Jičín a Frýdek-Místek, kde zřizovatelem školy je především kraj, na druhém místě jsou soukromé školy, jak je vidět v tabulce 5 . Dotazník byl elektronicky zaslán a vyplněn ředitelstvím školy.

Tabulka 5: Zřizovatelé škol u zkoumaného vzorku

\begin{tabular}{|l|c|}
\hline Zřizovatel & Počet škol \\
\hline Kraj/Obec/MŠMT & 24 \\
\hline Církev & 1 \\
\hline Soukromník & 9 \\
\hline Celkem & 34 \\
\hline
\end{tabular}

Zdroj: vlastní

\footnotetext{
${ }^{2}$ Veřejná správa [online][vid. 03. 10. 2014 ] Dostupné z http://verejna-sprava.krmoravskoslezsky.cz/assets/sk/dz_msk_2012_fin_27_3.pdf
} 
Především šlo o školy, kde počet žáků nepřesáhne 1000 a průměrný počet žáků je 400 - 600 . Primární výzkum probíhal pomocí dotazníkového šetření a rozhovoru se záznamem.

\subsection{Použitá metodika}

Zpracovaná data $\mathrm{z}$ dotazníkového šetření byla roztříděná do přehledných tabulek $\mathrm{s}$ těmito informacemi: pořadové čísla obměny (i) a hodnota znaku $\left(\mathrm{x}_{\mathrm{i}}\right)$, absolutní četnost $\left(\mathrm{n}_{\mathrm{i}}\right)$, relativní četnost $\left(\mathrm{p}_{\mathrm{i}}\right)$ a kumulativní četnost $\left(\mathrm{kp}_{\mathrm{i}}\right)$.

Četnost udává, kolik hodnot daného znaku se vyskytuje ve statistickém souboru - bud' absolutně, nebo relativně vzhledem k celkovému počtu prvků souboru. Statistický soubor je množina a množina jako taková nepřipouští, aby v ní bylo více stejných prvků. Takže absolutní četnost hodnoty statistického znaku $x$ udává počet výskytů znaku $x$ ve statistickém souboru

$$
p_{i}=\frac{n_{i}}{N}
$$

Relativní četnost (1) je počet hodnot $\mathrm{v}$ daném intervalu vztažený $\mathrm{k}$ celkovému počtu hodnot. Vyjadřuje, jaké procento všech hodnot leží v daném intervalu. Udává se obvykle jako desetinné číslo od 0 do 1 . Součet relativních četností je roven jedné. Výhodou je nezávislost na počtu hodnot ve výběru. Proto jsou relativní četnosti vhodné i k porovnávání dvou výběrů o nestejných velikostech. Relativní četnost se v praxi vyjadřuje v procentech. Kumulativní absolutní četnost udává počet hodnot menších než zadané číslo. Vyjadřuje součet všech předcházejících absolutních četností. Relativní kumulativní četnost se vypočte vydělením př́slušné absolutní kumulativní četnosti celkovým počtem hodnot nebo sečtením relativních četností v intervalech, jejichž horní hranice je menší než zadané číslo (Řezánková 2007).

Absolutní i relativní četnosti je možné počítat nejen pro kvantitativní data, ale i pro data nominální a ordinální. Pro ordinální data má často i smysl počítat kumulativní četnosti. Aby se četnosti mohly sčítat, je nutno hlavně dodržet zásadu neslučitelnosti kategorií.

Úroveň u nominální proměnné je charakterizována modální kategorií, což je největší četnost.

Kde

$$
\max _{i}(n i)=n_{\text {мо }}
$$

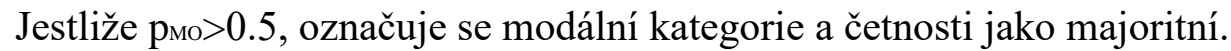

Základem pro zkoumání variability je zjištění koncentrace, kde lze jako míru koncentrace pro nominální proměnné použít relativní četnost modální kategorie:

$$
p_{M O}=\frac{n_{M O}}{n}
$$

Jako míru variability se spočítá variační poměr:

$$
v=1-p_{M O}=1-\frac{n_{M O}}{n}
$$

Míru variability lze také vyjádřit z hodnot intervalu od 0 do 1 , kde vypočítanou hodnotu podle výše uvedených vzorců dělíme maximální možnou hodnotou. (Řezánková 2007) 


\subsection{Dotazníkové šetření}

Dotazník byl koncipován formou uzavřených otázek, hodnoty znaku tedy byly kódované odpovědi neboli kategorie. Odpovědi jsou samostatné proměnné tvořící škálu hodnot. Podle typu škály byly proměnné zařazeny jako nominální proměnné. Hodnoty nominální proměnné se ve statistických programech zadávají jako čísla, s nimiž se neprovádějí aritmetické operace. Jde tedy pouze o číselné kódy, které nemají význam čísla. Pro měření názorů a postojů byly využity Likertovy škálové otázky. Škála byla sestavena s lichým počtem stupňů vyjadřující od nesouhlasu k souhlasu (Přibová 1996). Pro jednoduchost se v použitém datovém souboru nevyskytují chybějící údaje.

Dotazníkové šetření proběhlo na vybraných školách a jeho hlavním cílem bylo ověření proveditelnosti dotazníkového šetření a správnost stanovení hypotéz. Návratnost byla $100 \%$, nebot' školy odpovídaly elektronicky, a pokud dotazník z dané školy nebyl vyplněn, dotazování proběhlo osobně nebo telefonicky.

Byly formulovány tři základní výzkumné otázky:

- Má škola jasně stanovenou dlouhodobou vizi, cíle a strategii formulovanou do strategické koncepce, která je inovována a sdílena?

- Je marketingová koncepce úspěšná a efektivní a pomáhá škole prosadit se v konkurenčním prostředí?

- Formuluje škola svou vlastní marketingovou strategii na základě analýzy prostředí a analýzy marketingového mixu?

Při samotném výzkumu byly stanoveny a ověřeny hypotézy:

H1: Zřizovatel školy ovlivňuje tvorbu strategického marketingového řízení.

H2: Strategické marketingové plánování není závislé na délce existence školy.

Test nezávislosti slovních proměnných byl proveden na hladině významnosti $\alpha=0,05$. Síla závislosti byla měřená pomocí Cramérova kontingenčního koeficientu na základě intervalu $<-1,1>$. Závislost je silnější, pokud se hodnota koeficientu blíží jedné (Hindls 2000).

\subsection{Prezentace výsledků pilotního šetření}

Převážná většina zkoumaných škol vznikla před rokem 1989, jedná se tedy o školy, které mají dlouhodobou tradici. Předpoklad výzkumníka, že školy s dlouhou tradicí a větším počtem studentů se strategickým marketingovým plánem zabývají více, však není správný. Jedna ze zkoumaných otázek se zabývá závislostí mezi vzděláním ředitele a tvorbou strategických plánů. Ve vzorku převládá především vzdělání pedagogického směru, na druhém místě technický směr a pak ekonomický. Tato oblast bude dále zkoumána a je tedy možná závislost na koncepci vzdělávání ředitelů a znalostech a dovednostech v oblasti strategického řízení. Zejména zda ředitelé znají a umí sestavit strategický plán. V samotné koncepci dalšího vzdělávání ředitelů, tedy ve specializačním studiu, není na tuto oblast kladen důraz. Ředitelé se vzdělávají v oblasti legislativy, personalistiky a finančního řízení školy. Oblast strategického managementu a marketingu je opomíjena. Ve většině př́ípadů si ředitelé vytvoří koncepci rozvoje školy, která je povinná ke konkurznímu ř́zení, ale po nástupu do funkce se dál již jedná pouze o dokument, který se neaktualizuje, ani se nesdílí v rámci školy. Počet let ředitele ve funkci je v podstatě neutrální otázka bez dalších vazeb, a proto bude ve výzkumu vypuštěna. Počet pedagogů závisí 
na velikosti školy a tedy 30 a více pedagogů odpovídá velikosti školy s 400-800 žáky. Počet pedagogů, kteří nemají potřebné vzdělání, výrazně mění nabízenou kvalitu školy. Ve všech př́padech se však jedná o malé procento a $z$ dotazování vyplynulo, že většinou si tito pedagogové své vzdělání doplňují. Školy nemají problém s dosahovanou kvalifikací, ale s aprobovaností pedagogů. Stále chybí aprobovaní pedagogové cizích jazyků. Nejčastější problémy, se kterými se ředitelé potýkají, je nedostatek financí, špatná spolupráce se zřizovatelem nebo legislativní požadavky. Přes $70 \%$ zkoumaných středních škol má ve svém okolí do 40 km konkurenční školu nebo obor a vnímá své chování jako tržní. Předpokladem tedy je, že škola, která má konkurenci, by se měla strategickým řízením více zabývat.

Pojem marketing není školám neznámý. Ve většině případů (87 \%) ho mají spojený s tvorbou firemní kultury a dobrého klimatu školy. Problémem ovšem je, zda školy opravdu vědí, co do firemní kultury patří a jak se měří klima školy (tyto oblasti budou pak doplněny ve výzkumu). Každá škola využíá marketingovou komunikaci. Mezi nejčastěji používané prvky marketingové komunikace patří školní www stránky, FB a sociální sítě a propagační materiály škol, jak je vidět na obrázku 2. Reklamu nevyužívá v současné době ani jedna škola ze zkoumaného vzorku. Ve velmi malém zastoupení se objevuje také Event a PR.

Obrázek 2: Marketingová komunikace ve sledovaném vzorku středních škol

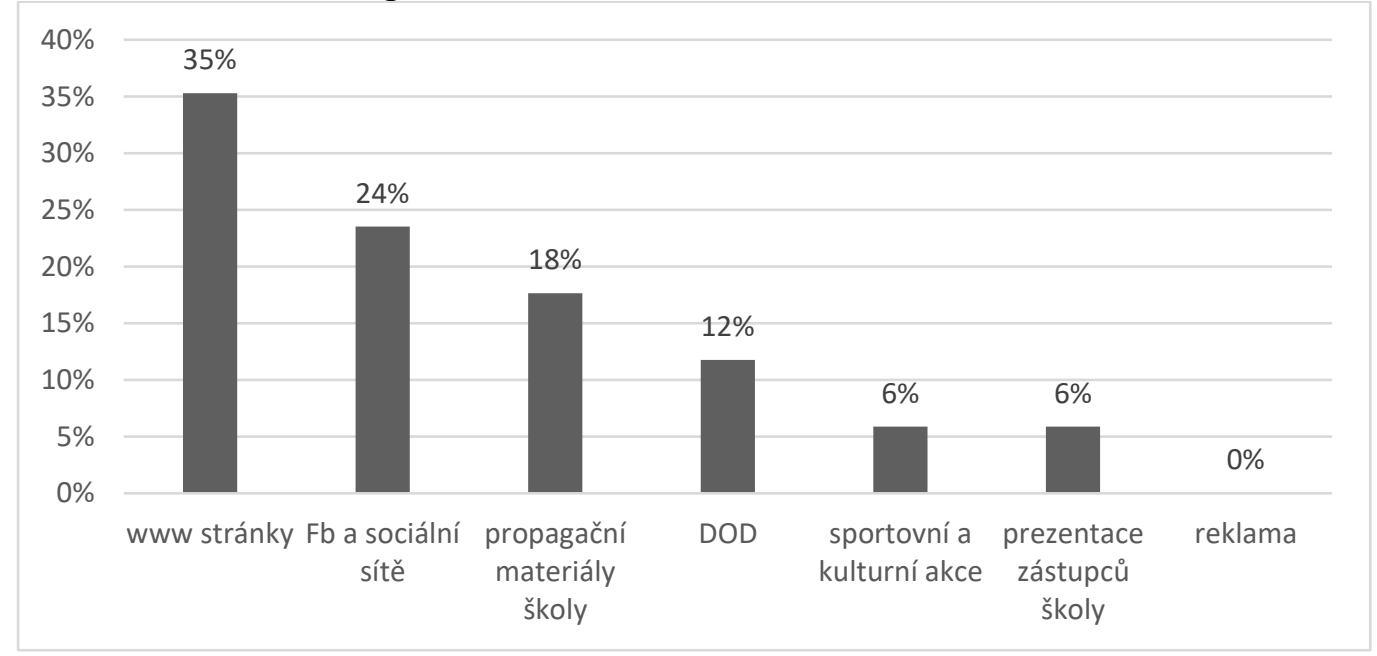

Zdroj: Vlastní zpracování

Cílem výzkumu bylo zodpovědět tři základní výzkumné otázky, ke kterým ředitelé vyjadřovali míru souhlasu:

- Škola má jasně stanovenou dlouhodobou vizi, cíle a strategii formulovanou do strategické koncepce, která je inovována a sdílena

Tabulka 6: Formulace strategické koncepce ve zkoumaných školách

\begin{tabular}{|l|c|c|}
\hline míra souhlasu $\mathrm{x}_{\mathrm{i}}$ & $\mathrm{p}_{\mathrm{i}} \%$ & $\mathrm{kp}_{\mathrm{i}} \%$ \\
\hline souhlasím & 13,843 & 13,840 \\
\hline $\begin{array}{l}\text { nezaujímám žádný } \\
\text { postoj }\end{array}$ & 2,564 & 16,407 \\
\hline nesouhlasím & 83,593 & 100,000 \\
\hline celkem & 100,000 & $\mathrm{x}$ \\
\hline
\end{tabular}

Zdroj: Vlastní zpracování 
Ředitelé si uvědomují, že strategická koncepce ve školách chybí. S tímto výrokem vyjádřilo nesouhlas $84 \%$ dotázaných ředitelů. Modální kategorie je tedy nesouhlas s tvrzením.

- Marketingová koncepce je úspěšná a efektivní a pomáhá škole se prosadit v konkurenčním prostředí

Tabulka 7: Efektivnost marketingové koncepce ve zkoumaných školách

\begin{tabular}{|l|c|c|}
\hline míra souhlasu $\mathrm{x}_{\mathrm{i}}$ & $\mathrm{p}_{\mathrm{i}} \%$ & $\mathrm{kp}_{\mathrm{i}} \%$ \\
\hline souhlasím & 74,641 & 74,641 \\
\hline $\begin{array}{l}\text { nezaujímám žádný } \\
\text { postoj }\end{array}$ & 1,081 & 75,722 \\
\hline nesouhlasím & 24,278 & 100,000 \\
\hline celkem & 100,000 & $\mathrm{x}$ \\
\hline
\end{tabular}

Zdroj: Vlastní zpracování

Většina ředitelů škol vnímá svou marketingovou strategii pozitivně a souhlasí s tvrzením. Modální kategorie je souhlas s tvrzením.

- Škola svou vlastní marketingovou strategii formuluje na základě analýzy prostředí a analýzy marketingového mixu

Tabulka 8: Provádění analýz při tvorbě a formulaci marketingové strategie

\begin{tabular}{|l|c|c|}
\hline míra souhlasu $\mathrm{x}_{\mathrm{i}}$ & $\mathrm{p}_{\mathrm{i}} \%$ & $\mathrm{kp}_{\mathrm{i}} \%$ \\
\hline souhlasím & 17,495 & 17,495 \\
\hline $\begin{array}{l}\text { nezaujímám žádný } \\
\text { postoj }\end{array}$ & 5,871 & 23,366 \\
\hline $\begin{array}{l}\text { nesouhlasím } \\
\text { celkem }\end{array}$ & 76,634 & 100,000 \\
\hline
\end{tabular}

Zdroj: Vlastní zpracování

Při dotazování vyplynulo, že analýza prostředí a marketingového mixu není součástí marketingové strategie ve školách. Veškeré marketingové aktivity dělají školy náhodně a spíše provádějí analýzu konkurence, tzn. Marketingovou strategii konkurenčních i nekonkurenčních škol, a bud' ji okopírují, nebo vytvářejí na jejím základě svoji. Modální kategorie je nesouhlas. $77 \%$ ředitelů nesouhlasí s tímto tvrzením.

Test nezávislosti slovních proměnných byl použitý na ověření hypotéz:

H1: Zřizovatel školy ovlivňuje tvorbu strategického marketingového řízení.

H2: Strategické marketingové plánování není závislé na délce existence školy.

Kdo je zřizovatelem školy a jaký je jeho celkový vliv na tvorbu strategického marketingového řízení? Předpokladem je, že školy, kde je zrrizovatelem firma nebo fyzická osoba, se budou chovat více tržně a $\mathrm{v}$ jejich koncepci řízení bude mít své místo i strategický marketingový plán. 
Tabulka 9: Ověření H1: Zřizovatel školy ovlivňuje tvorbu strat. marketingového řízení.

\begin{tabular}{|c|c|c|c|c|c|c|}
\hline Hypotéza & Test & $\begin{array}{c}\text { Hladina } \\
\text { spolehlivosti }\end{array}$ & Statistic & Df & P-Value & Cramerś \\
\hline 1 & test nezávislosti & $95 \%$ & 6,878 & 1 & 0,0081 & 0,2751 \\
\hline
\end{tabular}

Zdroj: Vlastní zpracování

H1 je závislá tzn., že zřizovatel školy ovlivňuje celkové strategické marketingové řízení, ale síla závislosti je středně vysoká.

Délka existence školy je velmi důležitá, nebot' se může podílet i na historii dané oblasti a samozřejmě na veřejném životě. Předpokladem je, že čím je škola starší a veřejnosti známější, nebude se marketingem až tak zabývat.

Tabulka 10: Ověření H2: Strat. marketingové plánování není závislé na délce existence školy.

\begin{tabular}{|c|c|c|c|c|c|c|}
\hline Hypotéza & Test & $\begin{array}{c}\text { Hladina } \\
\text { spolehlivosti }\end{array}$ & Statistic & Df & P-Value & Cramerś \\
\hline 2 & test nezávislosti & $95 \%$ & 9,375 & 5 & 0,0894 & \\
\hline
\end{tabular}

Zdroj: Vlastní zpracování

Tvorba strategických marketingových plánů není závislá na délce existence školy. U hypotézy se nepodařilo prokázat závislost na délce existence školy a tvorbě marketingové strategie.

\section{Závěr}

Konkurence na trhu vzdělávání v souvislosti s poklesem demografické křivky sílí. Většina škol soupeří o žáky ale i o kvalitní pedagogy s jinými školami. Kvalita školy je pak jedním z nejsilnějších faktorů. Strategické řízení školy propojené se strategickým marketingovým plánem dává do souladu dlouhodobé cíle školy a tím i dlouhodobou existenci školy.

Výzkum ukazuje, že ve školách mají ponětí o tom, co je strategické řízení, marketingový mix nebo plán, ale ve většině případů to dělat neumějí nebo nevědí, jak na to. Jejich reakce jsou vesměs intuitivní. Při tvorbě koncepce školy nevycházejí ani z jednoduché SWOT analýzy. Při tvorbě strategie rozvoje školy se ve většině případů zaměřovali především na vnitřní prostředí školy, ne na cílové trhy a marketingový mix.

Cílem dotazníkového šetření bylo ověřit validitu dotazníku, hypotéz a zodpovědět výzkumné otázky. Hypotéza „H1: Zřizovatel školy ovlivňuje tvorbu strategického marketingového ř́zeni" “ byla potvrzena. Je tady zřejmé, že školy, které zřizuje firma, právnická nebo fyzická osoba, se chovají mnohem tržněji a uvědomují si potřebu strategického marketingového řízení. Marketingové strategické řízení je závislé na zřizovateli. Hypotéza „H2: Strategické marketingové plánování není závislé na délce existence školy" potvrzena nebyla. Časová existence školy tedy není při posuzování strategického marketingového řízení školy důležitá. Ředitelé se měli vyjádřit a odpovědět na stanovené výzkumné otázky. Na otázku „Má škola jasně stanovenou dlouhodobou vizi, cíle a strategii formulovanou do strategické koncepce, která je inovována a sdílená? " byla odpověd' ve většině př́ipadů negativní a ředitelé si absenci vizí, cílů a strategií ve školách uvědomují. Stejný názor mají také na otázku „Formuluje škola 
svou vlastní marketingovou strategii na základě analýzy prostředí a analýzy marketingového mixu? " Z toho vyplývá, že školy ve většině prrípadů strategické marketingové plánování dělat neumějí, ale snaží se jím zabývat a hledají cestu. To také ukázaly odpovědi na otázku „,Je marketingová koncepce úspěšná a efektivni a pomáhá škole prosadit se v konkurenčním prostředi?? " Ředitelé vědí, že marketing jim může pomoci v jejich práci a samozřejmě obstát v konkurenčním prostředí.

Prostředí školy je hodně odlišné od prostř̌edí výrobní firmy nebo obchodní společnosti. Přesto však existence trhu vzdělávacích služeb tyto subjekty spojuje. Strategickým marketingovým řízením může škola získat nástroje potřebné k efektivnímu vedení, což jí přináší lepší finanční zázemí, dlouhodobou existenci, dobré klima, a tím cestu ke kvalitní škole. Poskytování vzdělávacích služeb je dlouhodobý proces, který nereaguje na změny v poptávce okamžitě, proto by škola měla tuto dlouhodobost řízeně plánovat a vnímat potřeby trhu práce a zároveň i trhu vzdělávání.

\section{Literatura}

[1] EGER, L. a D. EGEROVÁ, 2000. Image školy. Liberec : TU v liberci, 2000. ISBN 807083-440-4.

[2] FORET, M., 2012. Marketingový průzkum. Praha : Biz Books, 2012. ISBN 978-80-2650038-4.

[3] FOTR, J. a kol., 2012. Tvorba strategie a strategické plánování. Praha : Grada, 2012. ISBN 978-80-247-3985-4.

[4] HANNAGAN, T. J., 1996. Marketing pro neziskový sektor. Praha : Management Press, 1996. 80-85943-07-7.

[5] HINDLS, R., S. HRONOVÁ a I. NOVÁK, 2000. Metody statistické analýzy pro ekonomy. Praha : Management Press, 2000. ISBN 80-7261-013-9.

[6] HORÁKOVÁ, H., 2003. Strategický marketing. Praha : Grada Publishing,a.s., 2003. str. 204. ISBN 80-247-0447-1.

[7] HORÁKOVÁ, I., 1992. Marketing v současné světové praxi. Praha : Grada, 1992. str. 368. ISBN 80-85424-83-5.

[8] CHRÁSTKA, M., 2007. Metody pedagogického výzkumu. Praha : Grada Publishing,a.s., 2007. ISBN 978-80-247-1369-4.

[9] JAKUBÍKOVÁ, D., 2009. Strategický marketing. Praha : grada Publishing, a.s., 2009. str. 272. ISBN 978-80-247-2690-8.

[10] JUNGER, J., 2008. Strategický management. Ostrava : VŠP, a.s., 2008. ISBN 978-807410-006-2.

[11] MICHALKO, M., 2007. Strategický management. Ostrava : VŠP,a.s., 2007.

[12] MULLEROVA, L. a P. DOULÍK, 2001. Vybrané kapitoly ze školského managementu. Ústí nad Labem : PF UJEP, 2001. ISBN 80-7044-374-X.

[13] NIRMALYA, K., 2008. Marketing jako strategie vedoucí k úspěchu. Praha : Grada, 2008. ISBN 978-80-247-2139-3.

[14] PAYNE, A., 1996. Marketing služeb. Praha : Grada Publishing,s.r.o., 1996. str. 248. ISBN 80-7169-276-X. 
[15] P̌̌IBOVÁ, M., 1996. Marketingový výzkum v praxi. Praha : Grada Publishing,a.s., 1996. ISBN 80-7169-299-9.

[16] ŘEZÁNKOVÁ, H., 2007. Analýza dat z dotazníkových šetření. Praha: professional Publishing, 2007. str. 215. ISBN 978-80-86946-49-8.

[17] SVĚTLÍK, J., 2009. Marketingové rízení školy. PRAHA : WOLTERS KLUWER ČR, 2009. 978-80-7357-494-9.

[18] Moravskoslezský kraj webový portál. Veřejná správa [online][vid. 03. 10.2014 ] Dostupné z http://verejna-sprava.kr-moravskoslezsky.cz/assets/sk/dz_msk_2012_fin_27_3.pdf

[19] ČESKO. Zákon č. 89/2012 Sb. ze dne 1. ledna 2014 Občanský zákoník, In: Sbirka zákonů České republiky. 2012, částka 33, s. 1026-1365. ISSN 1211-1244. Dostupný také z: Webový portál Zákony pro lidi.cz [online][vid. 15. záŕí 2015]. <http://www.zakonyprolidi.cz/cs/2012-89\#cast1hlava3-dill>

[20] ZATLOUKAL, T. a kol. 2016. Výroční zpráva České školní inspekce za školní rok 2015/2016. Praha : autor neznámý, 2016. 978-80-88-087-09-0. 